\title{
Inter- and transdisciplinary perspective on the integration of ecological processes into ecosystem services analysis in a mountain region
}

\author{
Robert Huber ${ }^{1 *}$, Simon Briner ${ }^{2}$, Harald Bugmann ${ }^{3}$, Ché Elkin $^{3}$, Christian Hirschi ${ }^{4}$, Roman Seidll, Rebecca Snell ${ }^{3}$ \\ and Andreas Rigling
}

\begin{abstract}
Introduction: Ecosystem goods and services (EGS) studies have had little impact on policy processes and real-world decision-making due to limited understanding of the interactions and feedbacks among ecological, social and economic processes. Here we present an inter- and transdisciplinary analysis of global change impacts on EGS provision in a European mountain region. Our aim is to evaluate the projected influence of ecological, economic and social drivers on future EGS provision and to show possible ways to address the predominant limitations of EGS studies.

Methods: The integrated findings from ecological experiments, mechanistic models of landscape dynamics, socio-economic land-use models, policy analysis and transdisciplinary stakeholder interactions are presented consecutively. Four regionally downscaled global change scenarios, for a case study region near Visp, Switzerland $\left(350 \mathrm{~km}^{2}\right)$, were used to examine the impacts of climate and socio-economic changes on four ecosystem services, i.e., food provision, timber production, net greenhouse gas emissions and protection from natural hazards.
\end{abstract}

Results: Our simulation results reveal four key aspects that influence the future provision of mountain EGS. First, we show the high spatial and temporal heterogeneity of EGS provision even in a small case study region. Second, we find that climate change impacts are much more pronounced for forest EGS, while changes to agricultural EGS result primarily from shifts in economic conditions. Third, our modeling results reveal the complex trade-offs associated with the different scenarios. Fourth, simulations illustrate the importance of interactions between environmental shifts and economic decisions. We discuss our simulation results with respect to both existing policy networks and transdisciplinary stakeholder interactions.

Conclusion: We describe a framework based on experiments and observations that effectively supports the integration of ecological processes into an integrative modeling chain of EGS provision in mountain regions, the political decision-making process and also transdisciplinary stakeholder interactions.

Keywords: Interdisciplinary research; Ecosystem services; Modeling; Scenario analysis; Policy process; Transdisciplinary research; Mountain regions

\footnotetext{
* Correspondence: robert.huber@wsl.ch

${ }^{1}$ Forest Dynamics, Swiss Federal Research Institute WSL, Zürcherstrasse 111,

$\mathrm{CH}-8903$ Birmensdorf, Switzerland

Full list of author information is available at the end of the article
} 


\section{Introduction}

The concept of ecosystem goods and services (EGS) provides a framework to analyze relationships between society and ecology in complex social-ecological systems (Reyers et al. 2010; MEA 2005). While there is no universally accepted typology of EGS (Haines-Young and Potschin 2009; Braat and de Groot 2012; Gómez-Baggethun et al. 2010), most EGS studies combine an evaluation of biophysical structures and processes with an evaluation of human, social and economic components that determine EGS benefits or values (Braat and de Groot 2012). Although a wide range of EGS studies have used this approach (reviewed in Seppelt et al. 2011), a challenge still remains, namely the effective integration of ecological, economic and social components into an internally consistent framework that can be used to project future changes in EGS and their response to different driving forces.

For many stakeholders, including government agencies (Euliss et al. 2011), it is important to have robust and consistent approaches when assessing the effect of management actions on ecological processes and changes in EGS. Such approaches, however, are confronted with four main challenges. First, the ecological understanding of EGS is often limited (Kremen 2005), and there is a lack of quantitative relationships among biodiversity, ecosystem components and processes and services (de Groot et al. 2010). In addition, even if a mechanistic understanding of these processes exists, feedbacks between and within social and ecological systems are often ignored (Nicholson et al. 2009) or prone to inconsistencies (Cumming et al. 2005). Second, EGS studies often neglect the economic aspects of marginality, ecosystem transitions and substitution effects (Fisher et al. 2008; Bateman et al. 2011; Farley 2012), and sometimes fail to consider socially relevant and stakeholderoriented approaches (Cowling et al. 2008; Reed et al. 2009). Third, valuation and monetization of EGS must be placed in a relevant socio-cultural context (Braat and de Groot 2012; Nelson et al. 2009) to ensure that the economic valuation of EGS is accurate and reflects regional characteristics (de Groot et al. 2012; Hein et al. 2006; Schaeffer 2008; Polasky and Segerson 2009). Fourth, while the EGS viewpoint facilitates an analysis of ecological processes from the ecological systems perspective, various scale differences and cross-scale dynamics (Young 2002; Cash et al. 2006) still make it difficult to obtain an integrative overview of ecological and human systems.

Thus, due to a limited understanding of the interactions and feedbacks among ecological, social, economic and political processes, EGS studies have, historically, had little impact on policy processes and real decision-making (Daily et al. 2009; Carpenter et al. 2009). Consequently, a wide range of inter- and transdisciplinary frameworks have emerged in recent years, not only to analyze EGS in the context of social-ecological systems (e.g., Chapin et al.
2006; Wainger and Mazzotta 2011; Diaz et al. 2011; Oteros-Rozas et al. 2012; Polasky and Segerson 2009; Collins et al. 2011; Rounsevell et al. 2010; Kremen et al. 2007; Seidl et al. 2013), but also to meet the challenge of defining indicators that allow an understanding of the feedbacks and interactions in EGS analyses (van Oudenhoven et al. 2012; Müller and Burkhard 2012; Wainger and Mazzotta 2011). In addition, modeling studies that link ecological process models with socio-economic land-use models and incorporate feedback mechanisms (Claessens et al. 2009; Bithell and Brasington 2009; Schreinemachers and Berger 2011; Gibon et al. 2010; Huber et al. 2013a) have become stateof-the-art in ecosystem services analysis.

This inter- and transdisciplinary study is part of the "Mountland" project, where we address global change impacts on EGS in three different European mountain regions (Huber et al. 2013b). The aim of the project was to identify land-use practices and alternative policy solutions that ensure the provision of EGS from agricultural land use and forestry in mountain regions subject to climate and landuse changes. The main results from this project, which was conducted in the three different case study regions, are summarized and synthesized in Huber et al. (2013c). The simulation results presented here complement this work by providing an overview of our integrative assessment considering all four scenario families in the Special Report on Emission Scenarios (SRES) from the Intergovernmental Panel on Climate Change (IPCC 2000). The value of this contribution lies in the illustration of a successful application of inter- and transdisciplinary research from joint scenario development to simulation results and policy analysis in one case study region. We analyze and describe the spatial and temporal variance and similarities between regionally downscaled SRES and the four associated climate scenarios with regard to the provision of four mountain EGS (i.e., food provision, timber production, net greenhouse gas emissions and protection from natural hazards) in the case study region Visp, Switzerland. The comprehensive nature of our analysis allows us to assess how and where within the landscape climate and socio-economic factors influence EGS provision. The integration of our interdisciplinary results as well as transdisciplinary stakeholder interactions permit us to illustrate the importance of considering ecological processes throughout an integrative assessment of EGS provision. The discussion illustrates how we used inter- and transdisciplinary research to overcome limitations and to further our understanding of the interlinked ecological, social and economic processes in EGS studies.

\section{Data, methods and interdisciplinary workflow Case study region}

Central Valais is a drought-sensitive, continental, innerAlpine mountain area (Figure 1). It is suitable for studying 


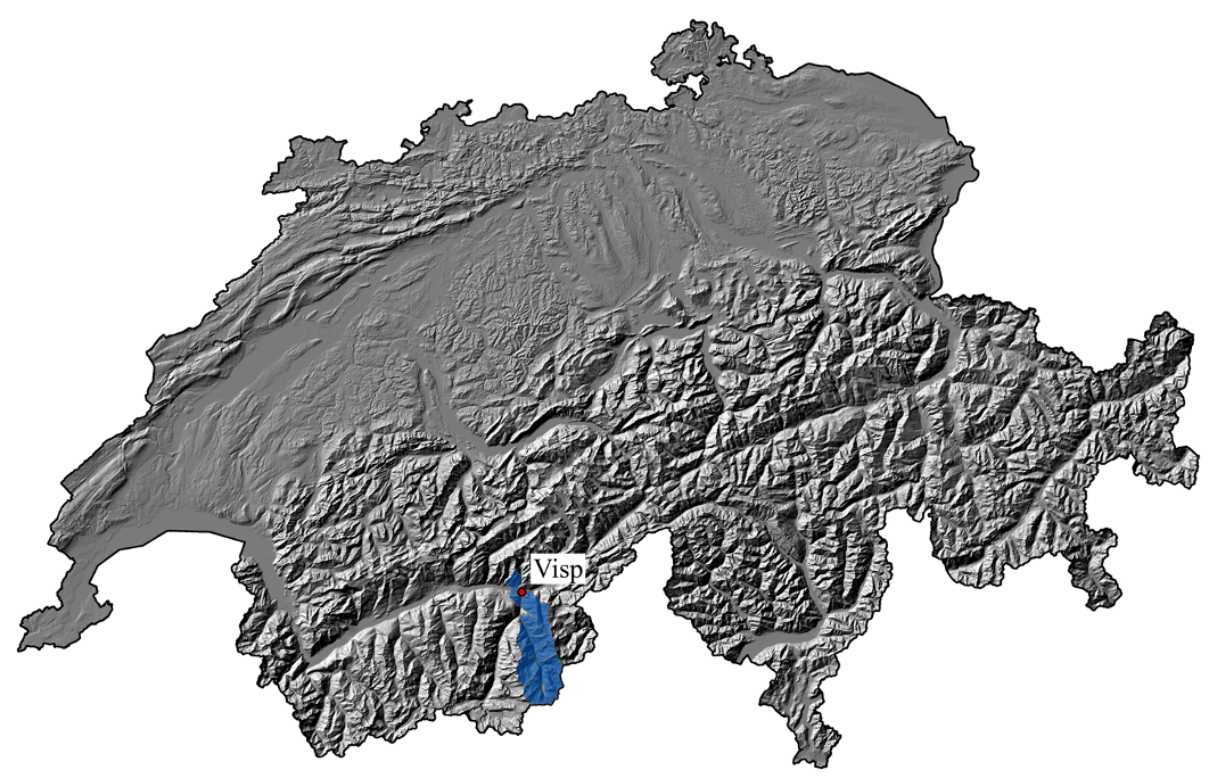

Figure 1 Map of Switzerland and the case study area Visp (in blue) in the Swiss Alps (provided by A. Psomoas, Swiss Federal Research Institute WSL).

the dynamics and diversity of mountain protection forests and grasslands and the influence of disturbances, in particular fire, insect and pathogen damage brought about by climate change (Rigling et al. 2013). The study area covers $350 \mathrm{~km}^{2}$ and has 15,000 inhabitants. Visp is a booming urban hotspot with industry and international traffic corridors. Saas Fee and Visperterminen are important destinations for summer and winter tourism. The Baltschieder valley is a remote, uninhabited Alpine side-valley with no infrastructure. Unproductive land accounts for $62 \%$ of the area, while $20 \%$ of the area is covered by forest and about $16 \%$ is used for agriculture. More than $98 \%$ of this agricultural land is grassland, and agricultural activities focus mainly on milk and meat production. Winter wheat and corn are the main crops cultivated in the bottom of the valley around Visp. On average, individual farmers cultivate less than 10 ha of agricultural land and keep around seven livestock units. Agricultural land use and forestry play an important role in the provision of recreation areas and habitats for plants and wildlife. Forest management is mainly in the hands of regional forest managers, with the primary aim of maintaining healthy forests that provide protection from rock fall and avalanche hazards. Timber production is of secondary importance due to high labor cost and low timber prices.

\section{Methodologies}

The combination of different methodological approaches within the project allows us to produce a robust evaluation of future EGS provision in mountain regions under global change, taking interactions between the ecological, socio-economic and policy domains into account
(Huber et al. 2013b). The main research findings from the Mountland project have been published in different interdisciplinary and disciplinary manuscripts (see Table 1). Thus, the workflow presented here does not describe every method in detail but instead focuses on the conceptual and practical link between the methodologies and the description of the interacting simulation frameworks. Figure 2 shows the general framework and the iterative procedure followed by the different research groups. More information on the technical integration of models and the corresponding assumptions can be found in the corresponding articles cited in Table 1.

\section{Scenario development}

We began our inter- and transdisciplinary research by formulating "context scenarios." In these scenarios, the consequences of global change at climate, market and policy levels are downscaled to the Visp region and summarized in regionally specific storylines consistent with the four IPCC SRES scenarios (Walz et al. 2013). We employed a formal technique of scenario construction which combines expert judgment with a quantitative, indicator-based selection algorithm. The resulting scenarios reflect the potential development pathways and interactions of major drivers for ecosystem service management and provide the input for a model-based analysis of ecosystem development and land-use decisionmaking.

\section{Ecological experiments and modeling}

To integrate knowledge of ecological processes into the Mountland model chain (green fields in Figure 2), 
Table 1 Research methodologies applied in the Mountland project

\begin{tabular}{|c|c|c|c|}
\hline Research discipline and focus & Methodology & Description & References \\
\hline \multirow{6}{*}{$\begin{array}{l}\text { Ecology (impact of global change } \\
\text { on forest processes and } \\
\text { ecosystem goods and services) }\end{array}$} & \multirow[t]{3}{*}{ Experiments } & $\begin{array}{l}\text { Afforestation (irrigated/non-irrigated, altitudinal } \\
\text { gradients, transplantations) }\end{array}$ & Eilmann et al. 2010, 2011 \\
\hline & & Rain-out shelter (under shelter/open land) & Eilmann and Rigling 2012 \\
\hline & & Thinnings (understory/overstory removal) & Rigling et al. 2013 \\
\hline & \multirow[t]{2}{*}{ Monitoring } & $\begin{array}{l}\text { National forest inventory and plots from the long-term } \\
\text { ecosystem monitoring program }\end{array}$ & \multirow{2}{*}{$\begin{array}{l}\text { Weber et al. 2008; } \\
\text { Wermelinger et al. 2008; } \\
\text { Zweifel et al. 2009; Rigling } \\
\text { et al. 2010; Heiniger et al. } \\
2011\end{array}$} \\
\hline & & $\begin{array}{l}\text { Additional temporal monitoring of plots (e.g., for } \\
\text { insects, mistletoe, pathogens) }\end{array}$ & \\
\hline & Modeling & $\begin{array}{l}\text { Forest dynamics and future forest states were } \\
\text { simulated using the landscape-scale model LandClim }\end{array}$ & $\begin{array}{l}\text { Elkin and Bugmann 2010; } \\
\text { Elkin et al. 2012, } 2013\end{array}$ \\
\hline \multirow[t]{2}{*}{$\begin{array}{l}\text { Socio-economic (land-use } \\
\text { change analysis under global } \\
\text { change) }\end{array}$} & Modeling & $\begin{array}{l}\text { Modeling concomitant effects of climate and land-use } \\
\text { change on the provision of ecosystem goods and services using } \\
\text { an activity-based, spatially explicit economic land allocation model }\end{array}$ & Briner et al. 2012, 2013a,b \\
\hline & $\begin{array}{l}\text { Formative } \\
\text { scenario } \\
\text { analysis }\end{array}$ & $\begin{array}{l}\text { Constructing consistent regional multi-scale scenarios by transdis- } \\
\text { ciplinary processes }\end{array}$ & Brand et al. 2013 \\
\hline \multirow[t]{2}{*}{$\begin{array}{l}\text { Policy analysis (identification of } \\
\text { best accepted policy strategies) }\end{array}$} & \multirow{2}{*}{$\begin{array}{l}\text { Policy } \\
\text { network and } \\
\text { policy } \\
\text { preferences } \\
\text { analysis }\end{array}$} & $\begin{array}{l}\text { Network structures and governance modes in adaptation policies } \\
\text { in the Canton of Valais; role of network governance in enhancing } \\
\text { sustainable development in mountain areas }\end{array}$ & $\begin{array}{l}\text { Ingold et al. 2010; Hirschi } \\
2010\end{array}$ \\
\hline & & $\begin{array}{l}\text { Network dynamics and policy preferences in Swiss agricultural } \\
\text { and forest policy }\end{array}$ & Hirschi et al. 2013 \\
\hline
\end{tabular}

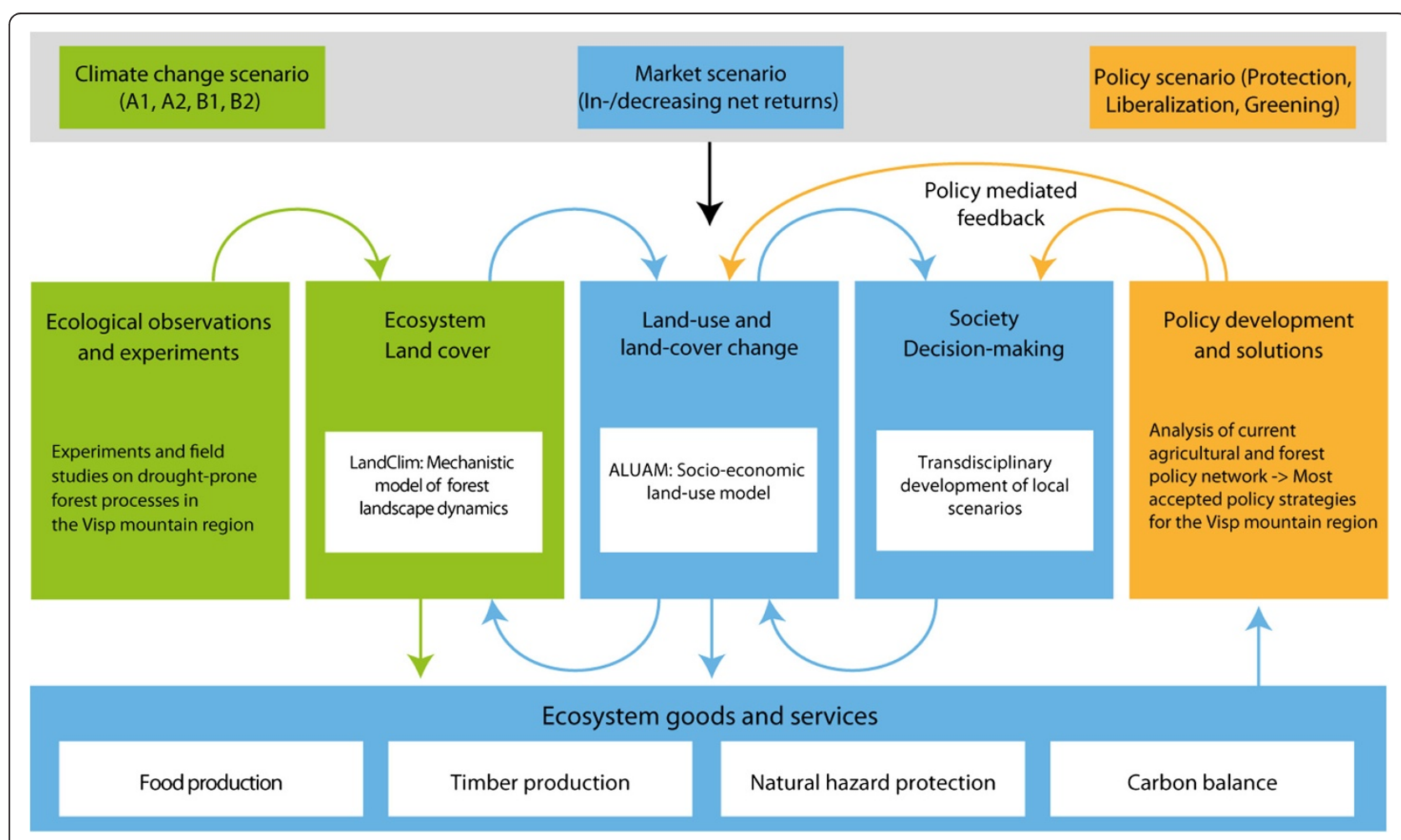

Figure 2 Conceptual framework of Mountland applied to the case study region Visp. Green fields refer to ecological research, blue to socio-economic research and orange to policy assessments. Source: Adapted from Huber et al. (2013b). 
findings from local ecological field studies and drought experiments (Brunner et al. 2009; Dobbertin et al. 2010; Eilmann and Rigling 2012; Eilmann et al. 2009, 2013; Rigling et al. 2013) were analyzed to improve the existing mechanistic forest model LandClim (Schumacher et al. 2004). LandClim is a spatially explicit processbased model that incorporates competition-driven forest dynamics and landscape-level disturbances to simulate forest dynamics at a landscape scale. LandClim was designed to examine the impact of climate change and forest management on forest development and structure (Schumacher and Bugmann 2006). The model simulates forest growth in $25 \times 25 \mathrm{~m}$ cells using simplified versions of tree recruitment, growth and competition processes. Individual cells are linked by the spatially explicit processes of seed dispersal, landscape disturbances and forest management. Forest growth is determined by climatic parameters, soil properties, topography, and large-scale disturbances, as well as forest management. We used our findings from the ecological field studies and drought experiments in the Visp region to calibrate and validate the LandClim simulations. Thus, empirical information on the effects of climate change on drought-prone forests in the Visp region (e.g., germination, growth and mortality of different tree species) was integrated into LandClim. This improved the ability of LandClim to simulate forest dynamics and project the impact of climate and land-use change on the spatially explicit provision of EGS at the landscape scale (Elkin et al. 2012).

\section{Socio-economic modeling}

The simulation results from LandClim were used as input for the analysis of socio-economic impacts (blue fields in Figure 2). The economic land-use optimization model ALUAM (Briner et al. 2012) simulates the competition between different agricultural land uses and forestry. The model results explicitly consider feedbacks and trade-offs between the economic gains from primary production and the provision of EGS under different scenarios (Briner et al. 2013a, b). The simple, modular structure of ALUAM facilitates a linkup of economic aspects with ecological and biophysical elements and the integration of datasets from different sources. Since the model also permits the introduction of possible new activities (e.g., irrigation), it is suitable for the simulation of strategies for adaptation to global change. In ALUAM, we assume that economic agents are profit maximizers. Combined with limited resources, represented by model restrictions, this normative model approach incorporates the fundamental economic problem at the margins, which is to make the most of limited resources (Buysse et al. 2007).

In ALUAM, decisions at the parcel, farm and regional level are optimized in such a way that aggregated land rent is maximized. At the parcel level, decisions concern land-use activities such as crop production, grassland intensity or timber production. Farm-level decisions relate to animal husbandry and flows of fodder and nutrients. Land use links the parcel level with livestock activities through fodder and nutrient balances. At the regional level, resources such as hirable workforce and number of animals available for grazing on summer pastures are only available to a limited extent and are therefore balanced over the whole region. Resource demands of activities at lower levels have to be evaluated to calculate these regional balances. A comparative static approach was used to assess the impact of our four scenarios in 2050 and 2080. We would refer to Briner et al. (2012, 2013a) for details regarding validation and sensitivity analysis of the model simulation.

A crop simulation model was used to integrate information concerning the impact of climate change on agricultural crop yields into ALUAM. This model calculates future yields of relevant crops using data on optimal and absolute crop growing conditions from the Food and Agriculture Organization (FAO) of the United Nations (FAO 2007). We fit a relative crop yield curve for temperature and precipitation values using an incomplete beta distribution. These species-specific crop yield curves serve to calculate the relative yield of crops and grassland for each landscape cell $(100 \times 100 \mathrm{~m})$ in the case study landscape based on monthly precipitation and temperature values.

\section{Transdisciplinary process}

The modular structure of ALUAM also allowed us to integrate local actors' decision-making into the optimization process using agent-based modeling techniques (Huber et al. 2013a; Hirschi et al. 2013). The use of agents with different preferences and attitudes towards agricultural activities meant we could integrate our findings from the transdisciplinary-based analysis of local decision-making into the model chain. The transdisciplinary process was set up as a cross-sectoral activity to provide guidance for the research process (Seidl et al. 2013). The stakeholder dialogue comprised two strongly inter-linked phases. In the first phase, a steering group representing the core stakeholders was set up in each study region. They consisted of six representatives of typical stakeholder groups who advised the project team from a "study region perspective." In the second phase, regional "transition scenarios" with extended stakeholder groups (10 to 15 representatives) were developed, using a functional-dynamic concept of stakeholder involvement. In four workshops, the research team worked closely with residents and policy-makers in the case study region to develop six local scenarios (Brand et al. 2013). However, in this article we refrain 
from applying agent-based techniques and use comparative static results. Given the long timeframe considered in our simulations (2080), the use of existing preferences is implausible.

\section{Policy assessment}

Finally, the model chain also allows for the integration of the knowledge on relevant policy issues studied (orange fields in Figure 2). We developed a policy-oriented indicator system for agricultural ecosystem services that can be linked to model-based scenario assessments (Hirschi et al. 2013). Specifically, we used policy network analysis to investigate the structural configuration of the relevant policy subsystems and analyzed the policy preferences of the main political actors in those policy subsystems to assess the feasibility of different policy options in the political process (Ingold et al. 2010; Hirschi 2010). This approach permits us to integrate policy-mediated feedback effects in our model chain. If the modeling outcome deviates greatly from the normative state of the corresponding indicator (i.e., derived from political goals as formulated in official policy documents of the federal government, and not from quantitative valuations), a policy change seems indicated.

\section{Indicators of ecosystem services \\ Food provision}

A wheat-equivalent index was calculated to assess food production. It considered the different values of crops and grassland for human nutrition, recognizing that grassland has a lower human nutritional value because grass must first be converted into milk or meat by animals. Crops that can be digested directly by humans, such as wheat, have a higher nutritional value than grassland. For a detailed description of the index, see Briner et al. (2012). During the optimization process, food provision was calculated as a direct function of the number of animals and the proportion of land in different land-use categories. Food production is impacted by climate change through the spatially explicit yield data provided by the crop model on which the optimization process is based.

\section{Timber production}

Potential timber production within each landscape cell was calculated using the LandClim model (Briner et al. 2012; Temperli et al. 2012). We implemented a forest management regime whereby forest stands are evaluated every 20 years to determine if the stand is ready to be entered and timber removed. If the average height of the dominant trees within a stand (largest 100 trees ha ${ }^{-1}$ ) is greater than $15 \mathrm{~m}$, all trees with a diameter at breast height $(\mathrm{DBH})$ greater than $20 \mathrm{~cm}$ are harvested. On average, harvested trees had a DBH between 25 and
$30 \mathrm{~cm}$. This management routine was used to obtain a potential timber production value for each cell in the landscape. The actual value of timber harvested was calculated in the ALUAM model, whereby production costs and timber prices were also taken into consideration.

\section{Natural hazard protection}

The ability of forests to provide protection against gravitational hazards, such as rock fall, depends on the location of forest stands as well as on the tree species mix, the structural profile, the rooting stability of live trees and the regeneration potential of the forest. We developed a metric that assesses the protection that forests provide against rock fall (Rockfall Protection Index RFPI; for details see Briner et al. 2013b). Rock fall protection was calculated using simulated forest data from LandClim. We then transferred the spatially explicit protection data to ALUAM, where the optimization process aggregated the potential RFPI of all parcels used as forests or fallow land to calculate the regional protection index.

\section{Carbon sequestration/release}

In our simulations, net greenhouse gas emissions are influenced by the amount of greenhouse gas (GHG) emitted by agriculture and the carbon sequestered (or emitted) by forests. In general, animal-based food production increases greenhouse gas emissions, and forest growth and timber production enhance sequestration. We accounted for all GHG emissions from agricultural activities, including indirect $\mathrm{N}_{2} \mathrm{O}$ emissions associated with $\mathrm{N}$ losses. The amount of greenhouse gases emitted depends primarily on the number of livestock kept in the region. Land use also has an impact on greenhouse gas emissions, as the number of tractor hours on extensively used grassland is lower than on intensively used grassland, and $\mathrm{CO}_{2}$ emissions are lower as well. In addition, nitrogen throughput is lower on extensively used land, causing lower nitrous oxide emissions. Carbon sequestration by forests was calculated as the amount of carbon immobilized each year in aboveground tree biomass. We assume that forest products lead to a displacement of fossil fuel-intensive products in housing construction and, thus, to a significant reduction in atmospheric carbon if timber is harvested (PerezGarcia et al. 2005). Only emissions inside the region were considered, and storage as soil organic carbon (e.g., Freibauer et al. 2004; Lal 2005) was not taken into account.

\section{Scenarios}

In Mountland, the global IPCC SRES scenarios regarding climatic, market and policy developments were regionally downscaled to produce case study-specific 
storylines that represent local conditions while remaining consistent with the global projections (Walz et al. 2013). This supports the view that global development and local land management are interdependent (Pahl-Wostl 2009). We used these storylines to adapt the economic scenarios provided by Abildtrup et al. (2006) to meet Swiss conditions. This allowed us to anchor the "context scenarios" in the overall climatic and socio-economic developments on a European level since this is most relevant for Swiss agricultural market developments. The scenarios provided in Abildtrup et al. (2006) provide a detailed and comprehensive development of prices and costs for different agricultural activities under the four global change scenarios. Table 2 summarizes the assumptions underlying the regional context scenarios (for details regarding driving forces, e.g., productivity changes and production resources, we refer to Walz et al. 2013).

The regional context scenario Growth and convergence is based on the SRES scenario A1FI, which implies rapid economic growth and an increase in average temperature of $4^{\circ} \mathrm{C}$ by 2080 . Global production processes put pressure on agricultural prices in Switzerland (with a high border protection and high domestic support-e.g., direct paymentsfor the agricultural sector). Agricultural policies are driven by market liberalization and a decrease in domestic support. To increase productivity, technological innovation in agriculture is high. Wood prices are assumed to remain constant.

Global development in the scenario Regional centers is characterized by a growing focus on self-sufficiency and preservation of local identities. The A2 scenario of the IPCC is assumed to be the underlying climate change scenario. The heterogeneous world in this scenario results in a more regional consumption pattern. Innovation rates in agriculture are rather low, and agricultural farm gate prices remain constant. Nature conservation policies decline, and national agricultural policy is dominated by protective measures (i.e., tariffs).
The Green growth scenario is characterized by more nature conservation policies and a greening of agricultural policy. Agricultural markets are less protected than today, but consumption patterns focus on certified products representing higher environmental standards. At the same time, innovation rates in agriculture are high. Despite more open market policies, there is only a slight decrease in agricultural farm gate prices, and the price of timber rises. The climate projection is based on the B1 scenario of the IPCC.

Local sustainability summarizes a context scenario which combines the B2 scenario with regional consumption patterns. The agricultural sector is characterized by low innovation rates and a decline in farm gate prices. Policies focus on more greening in the agricultural sector and more nature conservation. Timber prices are assumed to rise.

A summary of the parameter changes in ALUAM is presented in Additional file 1 (Table A1). Lastly, it is noteworthy that an increase in world market prices does not automatically translate into increasing prices on Swiss agricultural markets. Support for agricultural production in Switzerland still rates as one of the highest worldwide, and farm gate prices for milk and meat are over $40 \%$ higher compared to the European level (Huber and Lehmann 2010).

\section{Results}

Simulation results for relative changes in EGS provision for the years 2050 and 2080 are presented for food and timber provision (Figure 3) and for carbon sequestration and rock fall protection (Figure 4). To reflect the different climatic and ecological conditions in the case study region, we distinguish between low elevations in the main valley around Visp (400-800 m a.s.l.), intermediate elevations (8001,600 $\mathrm{m}$ a.s.l.) and high elevations (above 1,600 $\mathrm{m}$ a.s.l.). The scenarios are laid out according to the gradient with respect to the transitions from moderate to severe climate change impacts (B1, B2, A1, A2).

Table 2 "Context scenarios" for the case study region Visp

\begin{tabular}{lllll}
\hline & $\begin{array}{l}\text { Growth and } \\
\text { convergence }\end{array}$ & Regional centers & Green growth & Local sustainability \\
\hline Climate & A1Fl & A2 & B1 & B2 \\
Consumption patterns & Global production & Regional products & Certified products & Regional products \\
Agricultural markets & $\begin{array}{l}\text { Large decline in prices } \\
\text { (open markets) }\end{array}$ & $\begin{array}{l}\text { Stable prices (border } \\
\text { protection) }\end{array}$ & $\begin{array}{l}\text { Decline in prices (more } \\
\text { open markets) }\end{array}$ & $\begin{array}{l}\text { Stable prices (open markets but } \\
\text { increase in EU prices) }\end{array}$ \\
Wood prices & Stable prices & Stable prices & Increase in prices & Increase in prices \\
Technological innovation & High innovation rate & Low innovation rate & High innovation rate & Low innovation rate \\
in agriculture & Reduction & Reduction & Extension & Extension \\
Nature conservation & Liberalization & Reduced domestic & Greening (high domestic & Greening (high domestic support) \\
Agricultural policy & support & & & \\
\hline
\end{tabular}




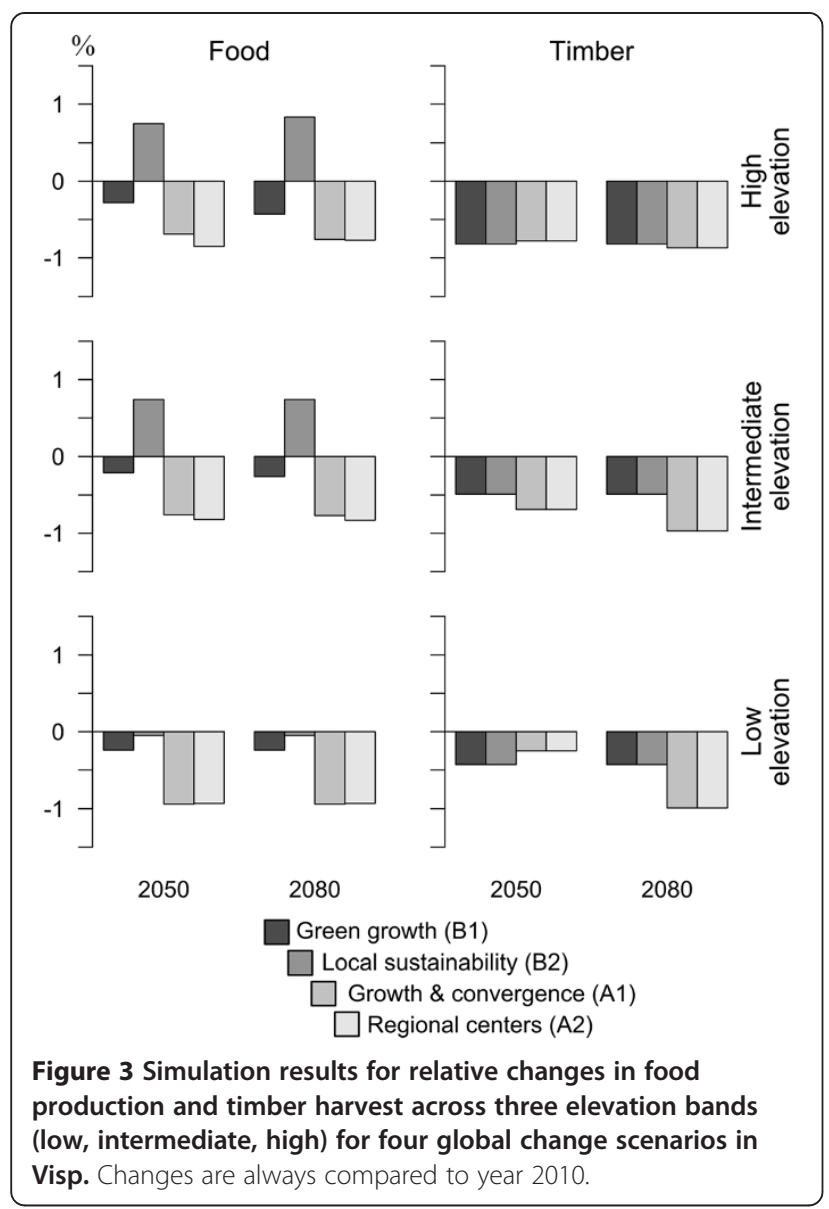

\section{Food provision}

Food production shows high variability between the families of A and B scenarios as well as between the two B scenarios. There are no appreciable differences between the two time steps 2050 and 2080 for any of the elevations. Specifically, food production declines strongly in the A scenarios. In the scenario Growth and convergence (A1), low prices for food and a reduction in agricultural support are projected to result in low intensity farming based mainly on low input meat and milk production. Two developments drive this drop in food provision. At low elevations, a shift from crop to milk production leads to a significant decline in food provision due to the lower human nutritional value of grassland compared to arable land. At higher elevations, simulation results show a decrease in the number of animals and land abandonment at marginal agronomic sites (for details of this scenario, see Briner et al. 2012). The results of the scenario Regional centers (A2) are based on the same two mechanisms. In contrast to the Growth and convergence (A1) scenario, however, these effects are not due to more open markets, but to a combination of low domestic support (i.e., direct payments) and an increase in costs which are associated with a more heterogeneous

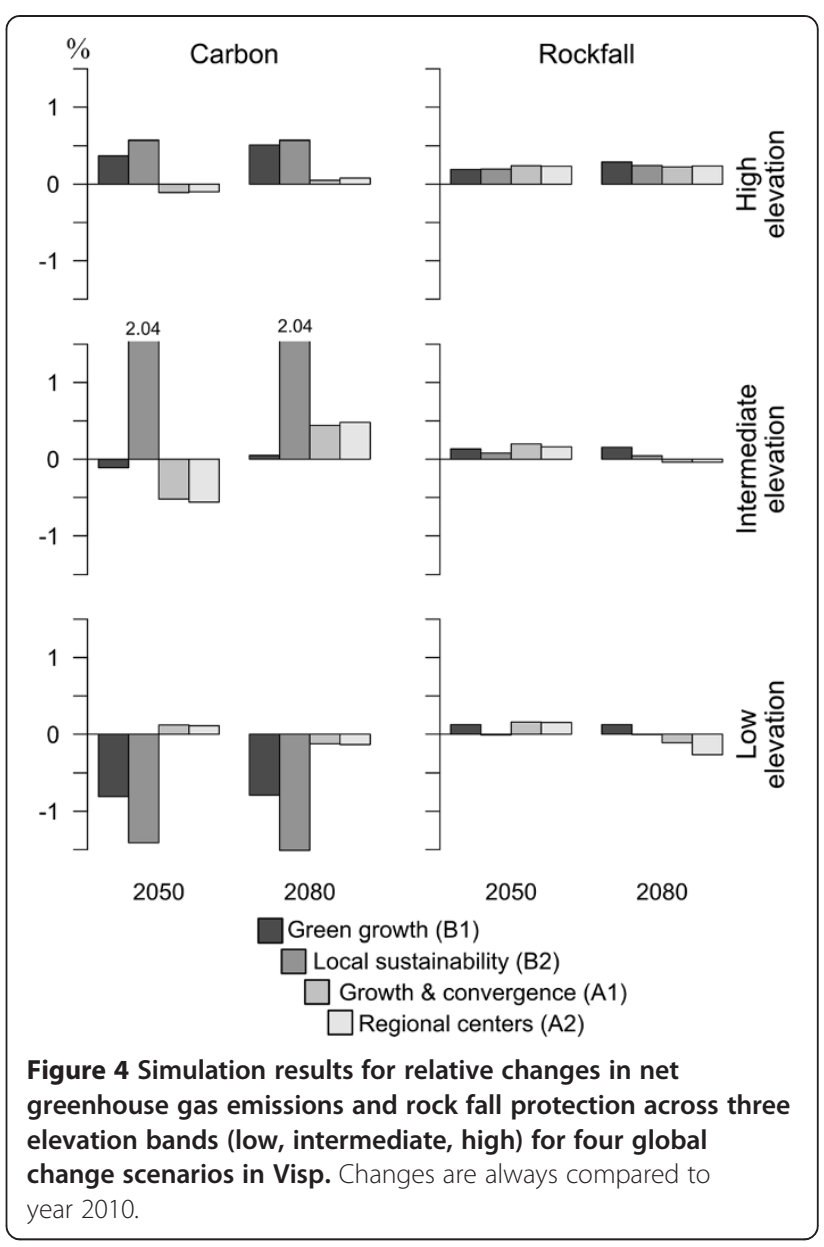

world in the A2 scenario. Food production is also lower in the Green growth (B1) scenario. However, some of the losses in economic returns are compensated by an increase in ecologically oriented direct payments. In the last scenario, Local sustainability (B2), these additional payments are combined with constant prices based on an increased level of European production prices. In this case, simulation results imply the reverse of the effects seen in the other scenarios. First, food production does not decline at lower elevations since arable land is used for crop production. Second, there is an increase in the number of animals kept for meat production (suckler cows and sheep) at intermediate and high elevations.

\section{Timber production}

Climate change is projected to have a differential impact on potential timber production along the elevational gradient and through time (Figure A1 in Additional file 1). At lower sites, drought leads to a decline in potential timber production and a shift towards more droughttolerant species. The reduction is accentuated for more severe climate scenarios (e.g., Growth and convergence [A1] and Regional centers [A2]) after 2050 when drought 
years become more frequent. In contrast, at intermediate and high elevations climate change is projected to increase potential timber production. However, the ALUAM simulation of the actual harvest, which also takes prices and costs for different types of wood into account, indicates that timber production declines in all scenarios and at all elevations (Figure 3). There are two reasons for this development. First, an increase in energy prices (i.e., fuel) makes the production of timber unprofitable on steep terrain even given a slight rise in prices under the scenarios Green growth (B1) and Local sustainability (B2). Second, drought-induced tree shifts lead to a scarcity of more profitable tree species, mainly at low and intermediate elevations. At low elevations, these effects are combined with a simulated reduction in potential timber production which is particularly accentuated in the scenarios Growth and convergence (A1) and Regional centers (A2) in 2080. The increase in potential timber production at high elevations is dominated by Picea abies, which is found to be less profitable in our simulations compared to the current market situation. In addition to the direct impacts of changes in climate and market forces, forest EGS provision at high elevations is affected by land-use change, i.e., when agricultural land is abandoned. However, the direct impact of climate and wood market changes are projected to have a greater effect on the state of the forest, and thus on timber production, than land-use changes (Briner et al. 2013a).

\section{Natural hazard protection}

In our case study region, climate change influences not only timber production but also the protection that forests provide against natural hazards such as rock fall. Thus, changes in natural hazard protection reflect general forest development, and this is dominated by a drought-induced decline in biomass and a shift towards more drought-tolerant tree species at low elevations and an increase in biomass production at higher elevations. Figure 5 illustrates the spatial heterogeneity in changes of the projected rock fall protection index by 2080 under the four scenarios. Rock fall protection decreases at lower elevations under the more severe climate scenarios and remains above the 2010 level only in the Green growth (B1) scenario. In contrast, protection from rock fall increases at high elevations in all scenarios. At intermediate elevations, rock fall protection declines slightly by 2080 in the scenarios based on more severe climate change, such as Growth and convergence (A1) and Regional centers (A2) which is illustrated by the aggregated indicator in Figure 4.

\section{Carbon sequestration/release}

Results in Figure 4 imply that greenhouse gas sequestration and release will differ significantly across scenarios and elevational gradients and over time. Projected increases in crop production and reductions in livestock numbers at lower elevations result in lower greenhouse gas emissions by agriculture in the scenarios Green growth (B1) and Local sustainability (B2) by 2050. However, simulation results for the Growth and convergence (A1) and Regional centers (A2) scenarios indicate a shift from crop to milk production and, thus, a slight increase in greenhouse gas emissions. The extensification of animal production is projected to reduce greenhouse gas emissions by 2080 in these scenarios. These effects over-

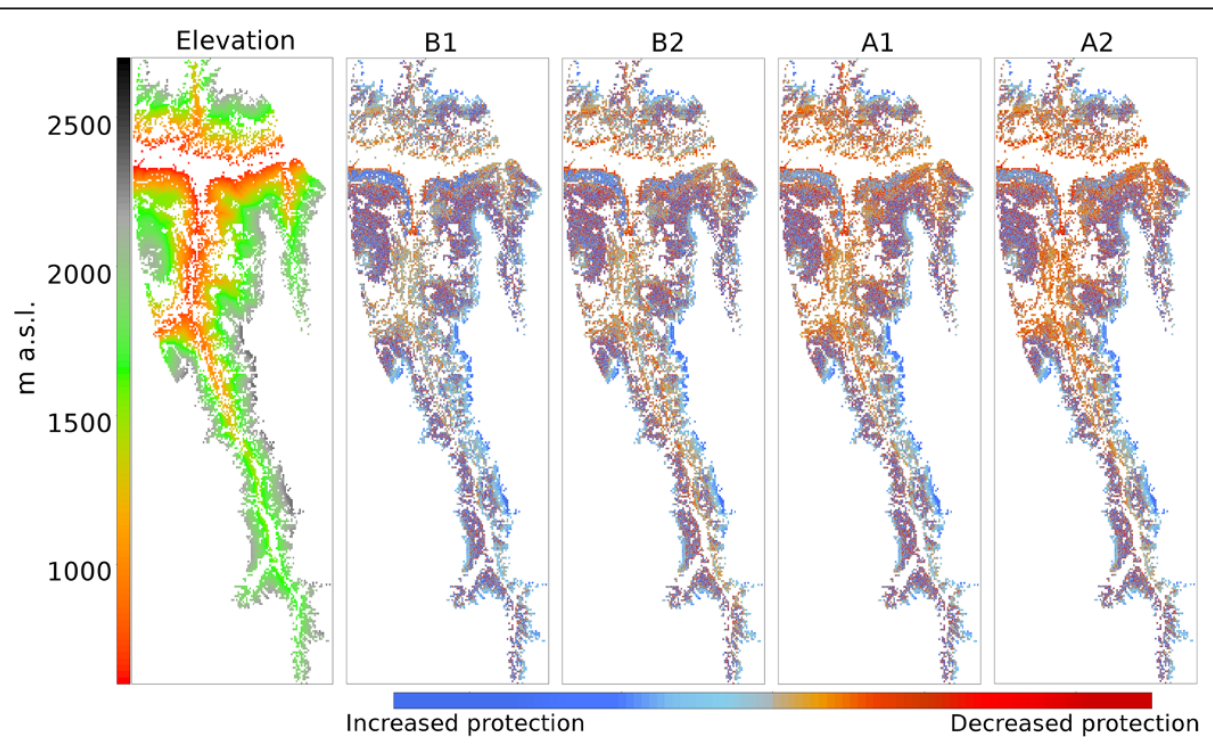

Figure 5 Spatially explicit provision of rock fall protection. The four context scenarios Green growth (B1), Local sustainability (B2), Growth and convergence (A1), and Regional centers (A2) are presented for the case study region Visp. 
compensate the lower carbon sequestration by forests arising from the decline in timber production and the drought-induced reduction in forest biomass. The increase in the number of animals at intermediate elevations in the Local sustainability (B2) scenario results in a large rise in greenhouse gas emissions compared to the 2010 level. In the other scenarios, however, the decline of timber harvesting and the corresponding loss of carbon sequestration outweigh the reduced greenhouse gas emission induced by a lower number of animals for the year 2080. This effect also leads to changes in net carbon sequestration at high elevations. The substantial reduction in timber harvest decreases net greenhouse gas sequestration for all scenarios by 2080 . Thus, the effect of reduced greenhouse gas emissions induced by a lower level of food provision in the Growth and convergence (A1), Regional centers (A2) and Green growth (B1) scenarios is not evident in the net balance of greenhouse gas emissions and carbon sequestration.

\section{Discussion}

\section{Discussion of scenario analysis}

Our simulation results illustrate the effect of global change impacts on EGS in a mountain case study region based on regional socio-economic and climate scenarios that are consistent with global IPCC SRES scenarios. Overall, given the different scenarios, the variance between the expected effects is high, even within IPCC SRES scenarios from the same family, such as Green growth (B1) and Local sustainability (B2).

The key findings can be summarized in four points. First, the scenario analysis revealed the spatial and temporal heterogeneity of EGS provision, even at a rather small $\left(350 \mathrm{~km}^{2}\right)$ regional scale. In this inner-alpine case study region, we found that EGS are highly vulnerable at all elevations, depending on the rate of climate change and the magnitude of socio-economic changes. Second, simulation results indicate that the impact of climatic change is much more pronounced for forest EGS compared to agricultural EGS. This reflects our findings that at low elevations, increasing drought is projected to reduce both forest biomass and provoke a switch towards more drought-tolerant tree species (Elkin et al. 2013). These results correspond with our experimental research in the same area, which provided important data for modeling drought and management effects for different tree species (Eilmann and Rigling 2012; Eilmann et al. 2009; Rigling et al. 2013). In contrast, changes to agricultural EGS were found to be due primarily to shifts in economic conditions that alter land use and land management (Briner et al. 2012, 2013a). Third, our simulation results suggest that trade-offs between different EGS will differ under the different scenarios, such as between food provision at higher elevations and increased agricultural greenhouse gas emissions. These trade-offs depend on the complex interactions of underlying structural and environmental conditions that are driven by socio-economic and climatic factors (Briner et al. 2013b). The emergence of trade-offs in an integrated modeling framework allowed us to address the economic aspects of marginality and substitution effects which are important in the valuation of EGS (e.g., Fisher et al. 2008; Bateman et al. 2011; Farley 2012). Fourth, our results demonstrate that land use and the associated provision of EGS are not only influenced directly by environmental shifts and economic decisions, but also depend strongly on the interactions between these two components (Briner et al. 2012).

As has been emphasized by many other authors (e.g., de Groot et al. 2002, 2010; Haines-Young and Potschin 2009; Carpenter et al. 2009), this latter aspect demonstrates the importance of including ecological processes in socio-economic modeling frameworks for the assessment of EGS. Ecological processes, such as the development of tree species under drought conditions or the variance in agricultural crop and grassland yields at higher temperatures and different elevational gradients, form a fundamental basis for the quantitative assessment of EGS changes. This would not have been possible in individual studies addressing forestry and agricultural activities in isolated socio-economic or ecological frameworks without feedbacks. This has also been demonstrated in other modeling studies addressing erosion (Claessens et al. 2009), hydrological cycles (Bithell and Brasington 2009), natural reforestation (Gibon et al. 2010) and habitat conservation (Huber et al. 2013a).

Spatially explicit modeling across scales and disciplines requires compromises, and there are several methodological aspects that should be considered within this context. The indicators that were used in our approach to link agricultural and forest activities to EGS provision, for instance, are more general than we would have liked, and indicators that allow for a more comprehensive illustration of the feedbacks between EGS would certainly improve our modeling results (e.g., van Oudenhoven et al. 2012; Müller and Burkhard 2012). In addition, the alignment of the time scales between the forest simulation model, which focuses on long-term developments, and the socio-economic land-use model, which has limited power in long-term projections (i.e., comparative static modeling approaches) remains a challenge (see Rounsevell and Arneth 2011). Furthermore, our spatially explicit approach allowed for landscape-level simulations that include relevant spatial dependencies on different scales (from plot-based observational and experimental findings to the region). However, we did not consider off-site effects (i.e., effects outside of the region being investigated), albeit they are an important facet in EGS 
analysis especially with respect to carbon sequestration (see Seppelt et al. 2011).

\section{Integrated modeling results in the context of policy processes and stakeholder interactions}

Our modeling results emphasize the importance of heterogeneity, trade-offs and feedbacks in the assessment of future EGS provision in mountain regions (see also $\mathrm{Hu}-$ ber et al. 2013c). However, quantitative scenario analysis will not suffice to bring EGS into policy and real decision-making processes, since societal values and political trade-offs must also be taken into account (Daily et al. 2009). In this context, taking into account policy processes and the consideration of stakeholders who actually manage resources in the respective area is a crucial aspect for EGS studies (e.g., Cowling et al. 2008; Daily and Matson 2008; Reed et al. 2009). Our research approach considered these factors by analyzing the policy network of central land use policies as well as by developing regional scenarios for the Visp area in collaboration with key stakeholders who are closely linked to the context scenarios presented here. We defined six consistent, multi-scale scenarios covering the global, the Swiss and the regional levels (i.e., the combination of the "context scenarios" presented here with local scenarios developed by the stakeholders). The scenarios represent possible futures and indicate strategies to cope with local and global challenges (Brand et al. 2013).

The results from the scenario development have two implications. First, when confronted with the consequences of global change impacts, local stakeholders became aware of a wider systematic and realistic picture. In our local scenario workshops, for example, stakeholders did not consider two out of the six multi-scale scenarios at the outset of the transdisciplinary process since the critical combination of climatic and economic risks in the region were implicitly avoided in the stakeholder discussions (Brand et al. 2013). Thus, the consideration of ecological processes and the use of mechanistic ecological models to produce quantitative projections of future states in transdisciplinary approaches turned out to be a useful means of confronting stakeholders with unwelcome, but nevertheless possible, prospects for the future rather than defining scenarios based on wishful thinking. Second, the results from the interdisciplinary process reveal that two impact factors (i.e., spatial planning and budget) represent the most important control factors for strategies addressing the challenges generated by global change in mountain regions. More importantly, local identity and the affinity local residents have to the region, its products and traditions, emerged as the most important, but also most ambivalent, elements of the social-ecological system analyzed. Thus, traditional landuse activities will play a crucial and yet unpredictable role in the future development of the Visp region.
In addition to stakeholder integration, the incorporation of more specific knowledge regarding the existing political structures and policy variables helped to make model-based ex-ante assessments of the future provision of EGS politically more realistic and, thus, more useful and relevant for actual policy-making processes (Hirschi et al. 2013). Within the Mountland project, we analyzed the political network structure of local infrastructure projects (Ingold et al. 2010) and the governance modes of regional adaptation measures, as well as the political dynamics and policy preferences in national agricultural and forest policy networks (Hirschi et al. 2013). The analyses revealed two central elements of relevant policy processes to effectively address the vulnerability of EGS in mountain regions. First, the promotion of integrative approaches, i.e., increased coordination of sectoral policies, and second, a more network-oriented management and steering of political processes with better integration of local stakeholders (Huber et al. 2013c).

However, our findings also reveal two important limitations that hinder the integration of EGS assessments, and thus a better consideration of ecological processes in policy-making. For instance, Ingold et al. (2010) showed that existing local policy projects give high consideration to regional planning as well as communal and economic interests, while most of the actors defending ecological concerns are not well embedded in the relevant information-exchange networks. Since there is a high degree of uncertainty, informal processes are most likely to gain increasing importance in the context of adaptation to climate change. In addition, our analysis of agricultural and forest policy networks showed a strong path-dependence and sectoral orientation of these two important land-use policies. This, combined with the dominance of economic interests, particularly in the agricultural sector, make major policy reforms in both sectors quite unlikely at present (Hirschi et al. 2013).

\section{Conclusions}

We have described a framework that effectively aids the integration of ecological processes based on experiments and observations into an integrative modeling chain of EGS provision in mountain regions, the political decision-making process and also transdisciplinary stakeholder interactions. Simulation results illustrated (i) the variance between regionally downscaled SRES scenarios, (ii) the different drivers for the future provision of EGS from forest and agriculture in the different scenarios, (iii) the different trade-offs in the four simulated scenarios and (iv) the importance of the consideration of social-ecological systems interactions. The discussion of these results in the context of policy processes and stakeholder interactions shows the usefulness of quantitative projections of future EGS anchored in the analysis 
of ecological processes in transdisciplinary approaches. It also reveals existing enabling factors and limitations that should be considered for a better integration of ecological processes in actual policy-making that wishes to address EGS provision.

\section{Additional file}

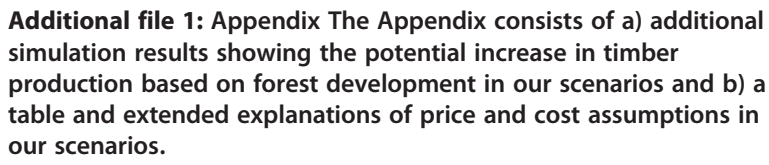

\section{Competing interests}

The authors declare that they have no competing interests.

\section{Authors' contributions}

$H B$ and $A R$ designed the research; SB, CE and RSe performed simulation analyses, $\mathrm{CH}$ performed policy analysis, RS performed transdisciplinary research; $\mathrm{RH}$ wrote the manuscript; $\mathrm{SB}, \mathrm{CE}, \mathrm{RS}$, $\mathrm{CH}, \mathrm{RSn}, \mathrm{HB}$ and $\mathrm{AR}$ reviewed and commented on various versions of the manuscript. All authors read and approved the final manuscript.

\section{Acknowledgements}

This work was supported by the CCES (Competence Centre Environment and Sustainability of the ETH Domain, Switzerland) as part of the Mountland project. We thank Jenny Bays for language corrections and the two anonymous reviewers, as well as the editors, for their constructive and helpful comments on earlier versions of the manuscript.

\section{Author details}

${ }^{1}$ Forest Dynamics, Swiss Federal Research Institute WSL, Zürcherstrasse 111, $\mathrm{CH}-8903$ Birmensdorf, Switzerland. ${ }^{2}$ Department of Environmental Systems Science, Agri-food and Agri-environmental Economics Group, ETH Zurich, $\mathrm{CH}-8092$ Zurich, Switzerland. ${ }^{3}$ Department of Environmental Systems Science, Forest Ecology, ETH Zurich, CH-8092 Zurich, Switzerland. ${ }^{4}$ Department of Environmental Systems Science, Environmental Policy and Economics, ETH Zurich, CH-8092 Zurich, Switzerland. ${ }^{5}$ Department of Environmental Systems Science, Natural and Social Science Interface, ETH Zurich, CH-8092 Zurich, Switzerland.

Received: 5 April 2013 Accepted: 7 November 2013 Published: 24 March 2014

\section{References}

Abildtrup J, Audsley E, Fekete-Farkas M, Giupponi C, Gylling M, Rosato P, Rounsevel M (2006) Socio-economic scenario development for the assessment of climate change impacts on agricultural land use: a pairwise comparison approach. Environ Sci Pol 9(2):101-115

Bateman I, Mace G, Fezzi C, Atkinson G, Turner K (2011) Economic analysis for ecosystem service assessments. Environ Resour Econ 48(2):177-218. doi:10.1007/ s10640-010-9418-x

Bithell M, Brasington J (2009) Coupling agent-based models of subsistence farming with individual-based forest models and dynamic models of water distribution. Environ Model Softw 24(2):173-190

Braat LC, de Groot R (2012) The ecosystem services agenda: bridging the worlds of natural science and economics, conservation and development, and public and private policy. Ecosyst Serv 1(1):4-15

Brand F, Seidl R, Le QB, Brändle J, Scholz RW (2013) Constructing consistent multiscale scenarios by transdisciplinary processes: the case of mountain regions facing global change. Ecol Soc 18(2):43

Briner S, Huber R, Elkin C, Grêt-Regamey A (2012) Assessing the impacts of economic and climate changes on land-use in mountain regions: a spatial dynamic modeling approach. Agr Ecosyst Environ 149(2012):50-63

Briner S, Elkin C, Huber R (2013a) Evaluating the relative impact of climate and economic changes on forest and agricultural ecosystem services in mountain regions. J Environ Manage 129(0):414-422. doi:http://dx.doi.org/10.1016/j.jenvman.2013.07.018.

Briner S, Huber R, Bebi P, Elkin C, Schmatz DR, Grêt-Regamey A (2013b) Trade-offs between ecosystem services in a mountain region. Ecol Soc 18(3). doi:10.5751/ES05576-180335

Brunner I, Pannatier EG, Frey B, Rigling A, Landolt W, Zimmermann S, Dobbertin M (2009) Morphological and physiological responses of Scots pine fine roots to water supply in a dry climatic region in Switzerland. Tree Physiol 29(4):541-550. doi:10.1093/treephys/tpn046.

Buysse J, van Huylenbroeck G, Lauwers L (2007) Normative, positive and econometric mathematical programming as tools for incorporation of multifunctionality in agricultural policy modelling. Agr Ecosyst Environ 120:70-81

Carpenter SR, Mooney HA, Agard J, Capistrano D, DeFries RS, Diaz S, Dietz T, Duraiappah AK, Oteng-Yeboah A, Pereira HM, Perrings C, Reid W, Sarukhan J, Scholes RJ, Whyte A (2009) Science for managing ecosystem services: beyond the Millennium Ecosystem Assessment. Proc Natl Acad Sci USA 106(5):1305-1312. doi:10.1073/pnas.0808772106.

Cash DW, Adger WN, Berkes F, Garden P, Lebel L, Olsson P, Pritchard L, Young O (2006) Scale and cross-scale dynamics: governance and information in a multilevel world. Ecol Soc 11(2):8

Chapin FS, Lovecraft AL, Zavaleta ES, Nelson J, Robards MD, Kofinas GP, Trainor SF, Peterson GD, Huntington HP, Naylor RL (2006) Policy strategies to address sustainability of Alaskan boreal forests in response to a directionally changing climate. Proc Natl Acad Sci USA 103(45):16637-16643. doi:10.1073/pnas.0606955103.

Claessens L, Schoorl JM, Verburg PH, Geraedts L, Veldkamp A (2009) Modelling interactions and feedback mechanisms between land use change and landscape processes. Agric Ecosyst Environ 129(1-3):157-170

Collins SL, Carpenter SR, Swinton SM, Orenstein DE, Childers DL, Gragson TL, Grimm NB, Grove JM, Harlan SL, Kaye JP, Knapp AK, Kofinas GP, Magnuson JJ, McDowell WH, Melack JM, Ogden LA, Robertson GP, Smith MD, Whitmer AC (2011) An integrated conceptual framework for long-term social-ecological research. Front Ecol Environ 9(6):351-357. doi:10.1890/100068.

Cowling RM, Egoh B, Knight AT, O'Farrell PJ, Reyers B, Rouget M, Roux DJ, Welz A Wilhelm-Rechman A (2008) An operational model for mainstreaming ecosystem services for implementation. Proc Natl Acad Sci USA 105(28):9483-9488. doi:10.1073/pnas.0706559105.

Cumming G, Alcamo J, Sala O, Swart R, Bennett E, Zurek M (2005) Are existing global scenarios consistent with ecological feedbacks? Ecosystems 8(2):143-152. doi:10.1007/s10021-004-0075-1.

Daily GC, Matson PA (2008) Ecosystem services: from theory to implementation. Proc Natl Acad Sci USA 105(28):9455-9456. doi:10.1073/pnas.0804960105.

Daily GC, Polasky S, Goldstein J, Kareiva PM, Mooney HA, Pejchar L, Ricketts TH, Salzman J, Shallenberger R (2009) Ecosystem services in decision making: time to deliver. Front Ecol Environ 7(1):21-28. doi:10.1890/080025.

de Groot RS, Wilson MA, Boumans RMJ (2002) A typology for the classification, description and valuation of ecosystem functions, goods and services. Ecol Econ 41(3):393-408

de Groot RS, Alkemade R, Braat L, Hein L, Willemen L (2010) Challenges in integrating the concept of ecosystem services and values in landscape planning, management and decision making. Ecol Complex 7(3):260-272. doi:http://dx.doi.org/10.1016/j.ecocom.2009.10.006.

de Groot R, Brander L, van der Ploeg S, Costanza R, Bernard F, Braat L, Christie M, Crossman N, Ghermandi A, Hein L, Hussain S, Kumar P, McVittie A, Portela R, Rodriguez LC, ten Brink $P$, van Beukering $P$ (2012) Global estimates of the value of ecosystems and their services in monetary units. Ecosyst Serv 1(1):50-61. doi:http://dx.doi.org/10.1016/j.ecoser.2012.07.005.

Diaz S, Quétier F, Caceres DM, Trainor SF, Pérez-Harguindeguy N, Bret-Harte MS, Finegan B, Pena-Claros M, Poorter L (2011) Linking functional diversity and social actor strategies in a framework for interdisciplinary analysis of nature's benefits to society. Proc Natl Acad Sci USA 108(3):895-902. doi:10.1073/pnas.1017993108.

Dobbertin M, Eilmann B, Bleuler P, Giuggiola A, Graf Pannatier E, Landolt W, Schleppi P, Rigling A (2010) Effect of irrigation on needle morphology, shoot and stem growth in a drought-exposed Pinus sylvestris forest. Tree Physiol 30(3):346-360. doi:10.1093/treephys/tpp123

FAO (Food and Agriculture Organization of the UN) (2007) Ecocrop. http://ecocrop.fao. org/ecocrop/srv/en/home.

Eilmann B, Rigling A (2012) Tree-growth analyses to estimate tree species' drought tolerance. Tree Physiol 32(2):178-187. doi:10.1093/treephys/tps004. 
Eilmann B, Zweifel R, Buchmann N, Fonti P, Rigling A (2009) Drought-induced adaptation of the xylem in Scots pine and pubescent oak. Tree Physiol 29(8):1011-1020. doi:10.1093/treephys/tpp035.

Eilmann B, Buchmann N, Siegwolf R, Saurer M, Cherubini P, Rigling A (2010) Fast response of Scots pine to improved water availability reflected in tree-ring width and 813C. Plant Cell Environ 33(8):1351-1360. doi:10.1111/j.13653040.2010.02153.x.

Eilmann B, Zweifel R, Buchmann N, Graf Pannatier E, Rigling A (2011) Drought alters timing, quantity, and quality of wood formation in Scots pine. J Exp Bot 62(8):2763-2771. doi:10.1093/jxb/erq443.

Eilmann B, Dobbertin M, Rigling A (2013) Growth response of Scots pine with different crown transparency status to drought release. Ann For Sci 70(7):685-693. doi:10.1007/s13595-013-0310-z.

Elkin C, Bugmann H (2010) Impact of climate change on ecosystem services in the Valais, Switzerland. In: Price M (ed) Europe's ecological backbone: recognising the true value of our mountains. European Environment Agency, Copenhagen, pp 67-70

Elkin C, Reineking B, Bigler C, Bugmann H (2012) Do small-grain processes matter for landscape scale questions? Sensitivity of a forest landscape model to the formulation of tree growth rate. Landsc Ecol 27(5):697-711. doi:10.1007/ s10980-012-9718-3.

Elkin C, Gutiérrez AG, Leuzinger S, Manusch C, Temperli C, Rasche L, Bugmann H (2013) A $2^{\circ} \mathrm{C}$ warmer world is not safe for ecosystem services in the European Alps. Glob Chang Biol 19(6):1827-1840. doi:10.1111/gcb.12156.

Euliss NH, Smith LM, Liu S, Duffy WG, Faulkner SP, Gleason RA, Eckles SD (2011) Integrating estimates of ecosystem services from conservation programs and practices into models for decision makers. Ecol Appl 21(sp1):S128-S134. doi:10.1890/09-0285.1

Farley J (2012) Ecosystem services: the economics debate. Ecosyst Serv 1(1):40-49

Fisher B, Turner K, Zylstra M, Brouwer R, Groot R, Farber S, Ferraro P, Green R, Hadley D, Harlow J, Jefferiss P, Kirkby C, Morling P, Mowatt S, Naidoo R, Paavola J, Strassburg B, Yu D, Balmford A (2008) Ecosystem services and economic theory: integration for policy-relevant research. Ecol Appl 18(8):2050-2067. doi:10.1890/07-1537.1.

Freibauer A, Rounsevell MDA, Smith P, Verhagen J (2004) Carbon sequestration in the agricultural soils of Europe. Geoderma 122(1):1-23. doi:http://dx.doi.org/10.1016/j.geoderma.2004.01.021.

Gibon A, Sheeren D, Monteil C, Ladet S, Balent G (2010) Modelling and simulating change in reforesting mountain landscapes using a socialecological framework. Landsc Ecol 25(2):267-285

Gómez-Baggethun E, de Groot R, Lomas PL, Montes C (2010) The history of ecosystem services in economic theory and practice: from early notions to markets and payment schemes. Ecol Econ 69(6):1209-1218

Haines-Young RH, Potschin MB (2009) Methodologies for defining and assessing ecosystem services. Final report, JNCC:69, project code C08-0170-0062. Centre for Environmental Management, Nottingham

Hein L, van Koppen K, de Groot RS, van lerland EC (2006) Spatial scales, stakeholders and the valuation of ecosystem services. Ecol Econ 57(2):209-228

Heiniger U, Theile F, Rigling A, Rigling D (2011) Blue-stain infections in roots, stems and branches of declining Pinus sylvestris trees in a dry inner alpine valley in Switzerland. For Pathol 41(6):501-509. doi:10.1111/j.14390329.2011.00713.x.

Hirschi C (2010) Strengthening regional cohesion: collaborative networks and sustainable development in Swiss rural areas. Ecol Soc 115(4):16. URL: http:// www.ecologyandsociety.org/vol15/iss4/art16/

Hirschi C, Widmer A, Briner S, Huber R (2013) Combining policy network and modelbased scenario analyses: an assessment of future ecosystem goods and services in Swiss mountain regions. Ecol Soc 18(2). doi:10.5751/ES-05480-180242.

Huber R, Lehmann B (2010) WTO agreement on agriculture: potential consequences for agricultural production and land-use patterns in the Swiss lowlands. Dan J Geogr 109(2):131-145

Huber R, Briner S, Peringer A, Lauber S, Seidl R, Widmer A, Gillet F, Buttler A, Le QB, Hirschi C (2013a) Modeling social-ecological feedback effects in the implementation of payments for environmental services in pasture-woodlands. Ecol Soc 18(2). doi:10.5751/ES-05487-180241.

Huber R, Bugmann H, Buttler A, Rigling A (2013b) Sustainable land-use practices in European mountain regions under global change: an integrated research approach. Ecol Soc 18(3). doi:10.5751/ES-05375-180337.

Huber R, Rigling A, Bebi P, Brand FS, Briner S, Buttler A, Elkin C, Gillet F, GrêtRegamey A, Hirschi C, Lischke H, Scholz RW, Seidl R, Spiegelberger T, Walz A,
Zimmermann W, Bugmann H (2013c) Sustainable land use in mountain regions under global change: synthesis across scales and disciplines. Ecol Soc 18(3). doi:10.5751/ES-05499-180336.

Ingold K, Balsiger J, Hirschi C (2010) Climate change in mountain regions: how local communities adapt to extreme events. Local Environ 15(7):651-661. doi:10.1080/13549839.2010.498811.

IPCC (2000) Emissions scenarios-summary for policymakers. A special report of IPCC Working Group III, Intergovernmental Panel on Climate Change. IPCC, Geneva

Kremen C (2005) Managing ecosystem services: what do we need to know about their ecology? Ecol Lett 8(5):468-479. doi:10.1111/j.1461-0248.2005.00751.x.

Kremen C, Williams NM, Aizen MA, Gemmill-Herren B, LeBuhn G, Minckley R, Packer L, Potts SG, Ta R, Steffan-Dewenter I, Vázquez DP, Winfree R, Adams L, Crone EE, Greenleaf SS, Keitt TH, Klein A-M, Regetz J, Ricketts TH (2007) Pollination and other ecosystem services produced by mobile organisms: a conceptual framework for the effects of land-use change. Ecol Lett 10 (4):299-314. doi:10.1111/j.1461-0248.2007.01018.x.

Lal R (2005) Forest soils and carbon sequestration. For Ecol Manage 220(1-3):242-258. doi:http://dx.doi.org/10.1016/j.foreco.2005.08.015.

MEA (2005) Millennium Ecosystem Assessment, ecosystems and human wellbeing: synthesis. Island Press, Washington DC

Müller F, Burkhard B (2012) The indicator side of ecosystem services. Ecosyst Serv 1(1):26-30

Nelson E, Mendoza G, Regetz J, Polasky S, Tallis H, Cameron D, Chan KMA, Daily GC, Goldstein J, Kareiva PM, Lonsdorf E, Naidoo R, Ricketts TH, Shaw M (2009) Modeling multiple ecosystem services, biodiversity conservation, commodity production, and tradeoffs at landscape scales. Front Ecol Environ 7(1):4-11. doi:10.1890/080023.

Nicholson E, Mace GM, Armsworth PR, Atkinson G, Buckle S, Clements T, Ewers RM, Fa JE, Gardner TA, Gibbons J, Grenyer R, Metcalfe R, Mourato S, Muûls M, Osborn D, Reuman DC, Watson C, Milner-Gulland EJ (2009) Priority research areas for ecosystem services in a changing world. J Appl Ecol 46(6):1139-1144. do::10.1111/j.1365-2664.2009.01716.x.

Oteros-Rozas E, Gonzalez J, Martin-Lopez B, Lopez C, Zorrilla-Miras P, Montes C (2012) Evaluating ecosystem services in transhumance cultural landscapesan interdisciplinary and participatory framework. GAIA Ecol Perspect Sci Soc 21(3):185-193

Pahl-Wostl C (2009) A conceptual framework for analysing adaptive capacity and multi-level learning processes in resource governance regimes. Glob Environ Chang 19(3):354-365. doi:http://dx.doi.org/10.1016/j.gloenvcha.2009.06.001.

Perez-Garcia J, Lippke B, Comnick J, Manriquez C (2005) An assessment of carbon pools, storage, and wood products market substitution using life-cycle analysis results. Wood Fiber Sci 37:140-148

Polasky S, Segerson K (2009) Integrating ecology and economics in the study of ecosystem services: some lessons learned. Annu Rev Resour Econ 1(1):409-434. doi:10.1146/annurev.resource.050708.144110.

Reed MS, Bonn A, Slee W, Beharry-Borg N, Birch J, Brown I, Burt TP, Chapman D, Chapman PJ, Clay GD, Cornell SJ, Fraser EDG, Glass JH, Holden J, Hodgson JA, Hubacek K, Irvine B, Jin N, Kirkby MJ, Kunin WE, Moore O, Moseley D, Prell C, Price MF, Quinn CH, Redpath S, Reid C, Stagl S, Stringer LC, Termansen M (2009) The future of the uplands. Land Use Pol 26(Supplement 1):S204-S216

Reyers B, Roux DJ, O'Farrell PJ (2010) Can ecosystem services lead ecology on a transdisciplinary pathway? Environ Conserv 37(04):501-511. doi:10.1017/ S0376892910000846.

Rigling A, Eilmann B, Koechli R, Dobbertin M (2010) Mistletoe-induced crown degradation in Scots pine in a xeric environment. Tree Physiol 30(7):845-852. doi:10.1093/ treephys/tpq038.

Rigling A, Bigler C, Eilmann B, Feldmeyer-Christe E, Gimmi U, Ginzler C, Graf U, Mayer P, Vacchiano G, Weber P, Wohlgemuth T, Zweifel R, Dobbertin M (2013) Driving factors of a vegetation shift from Scots pine to pubescent oak in dry Alpine forests. Glob Chang Biol 19(1):229-240. doi:10.1111/gcb.12038.

Rounsevell MDA, Arneth A (2011) Representing human behaviour and decisional processes in land system models as an integral component of the earth system. Glob Environ Chang 21(3):840-843

Rounsevell M, Dawson T, Harrison P (2010) A conceptual framework to assess the effects of environmental change on ecosystem services. Biodivers Conserv 19(10):2823-2842. doi:10.1007/s10531-010-9838-5.

Schaeffer PV (2008) Thoughts concerning the economic valuation of landscapes. J Environ Manage 89(3):146-154

Schreinemachers P, Berger T (2011) An agent-based simulation model of humanenvironment interactions in agricultural systems. Environ Model Softw 26(7):845-859 
Schumacher S, Bugmann H (2006) The relative importance of climatic effects, wildfires and management for future forest landscape dynamics in the Swiss Alps. Glob Chang Biol 12(8):1435-1450. doi:10.1111/j.1365-2486.2006.01188.x.

Schumacher S, Bugmann H, Mladenoff DJ (2004) Improving the formulation of tree growth and succession in a spatially explicit landscape model. Ecol Model 180(1):175-194

Seidl R, Brand F, Stauffacher M, Krütli P, Le Q, Spörri A, Meylan G, Moser C, González M, Scholz R (2013) Science with society in the anthropocene. AMBIO 42(1):5-12. doi:10.1007/s13280-012-0363-5.

Seppelt R, Dormann CF, Eppink FV, Lautenbach S, Schmidt S (2011) A quantitative review of ecosystem service studies: approaches, shortcomings and the road ahead. J Appl Ecol 48(3):630-636. doi:10.1111/j.13652664.2010.01952.x.

Temperli C, Bugmann HKM, Elkin C (2012) Adaptive management for competing forest goods and services under climate change. Ecol Appl 22:2065-2077. doi:10.1890/12-0210.1

van Oudenhoven APE, Petz K, Alkemade R, Hein L, de Groot RS (2012) Framework for systematic indicator selection to assess effects of land management on ecosystem services. Ecol Indic 21:110-122. doi:10.1016/j. ecolind.2012.01.012

Wainger L, Mazzotta M (2011) Realizing the potential of ecosystem services: a framework for relating ecological changes to economic benefits. Environ Manage 48(4):710-733. doi:10.1007/s00267-011-9726-0.

Walz A, Braendle JM, Lang DJ, Brand F, Briner S, Elkin C, Hirschi C, Huber R, Lischke H, Schmatz DR (2013) Experience from downscaling IPCC-SRES scenarios to specific national-level focus scenarios for ecosystem service management. Technol Forecast Soc Change. (in press), doi:http://dx.doi.org/10.1016/j.techfore.2013.08.014.

Weber P, Bugmann H, Fonti P, Rigling A (2008) Using a retrospective dynamic competition index to reconstruct forest succession. For Ecol Manage 254(1):96-106

Wermelinger B, Rigling A, Schneider Mathis D, Dobbertin M (2008) Assessing the role of bark- and wood-boring insects in the decline of Scots pine (Pinus sylvestris) in the Swiss Rhone valley. Ecol Entomol 33(2):239-249. doi:10.1111/j.1365-2311.2007.00960.x.

Young $O$ (2002) The institutional dimensions of environmental change: fit, interplay, and scale. MIT Press, Cambridge

Zweifel R, Rigling A, Dobbertin M (2009) Species-specific stomatal response of trees to drought-a link to vegetation dynamics? J Veg Sci 20(3):442-454. doi:10.1111/j.1654-1103.2009.05701.x.

doi:10.1186/2192-1709-3-9

Cite this article as: Huber et al:: Inter- and transdisciplinary perspective on the integration of ecological processes into ecosystem services analysis in a mountain region. Ecological Processes 2014 3:9.

\section{Submit your manuscript to a SpringerOpen ${ }^{\circ}$ journal and benefit from:}

- Convenient online submission

- Rigorous peer review

- Immediate publication on acceptance

- Open access: articles freely available online

- High visibility within the field

- Retaining the copyright to your article

Submit your next manuscript at $\boldsymbol{~ s p r i n g e r o p e n . c o m ~}$ 